\title{
Increasing Competitiveness of Micro, Small and Medium Enterprises Through the Application of Green Marketing Mix to Support for Tourism Sector
}

\author{
Erni Yuningsih ${ }^{1}$, Rachmat Gunawan ${ }^{2}$, Endang Silaningsih ${ }^{3}$ \\ \{erni.yuningsih@unida.ac.id ${ }^{1}$, rachmat.gunawan@unida.ac.id ${ }^{2}$,endang.silaningsih@unida.ac.id ${ }^{3}$ \} \\ Universitas Djuanda Bogor, Jalan Tol Ciawi ${ }^{1,2,3}$
}

\begin{abstract}
The research aims to determine 1) the application of green marketing mix to SMEs 2) study and analyze the effects of green marketing mix both simultaneously and partially in increasing competitiveness. The object of research for SMEs is food products and handicrafts. This research method is descriptive and verification. The data analysis technique used multiple linear regression analysis, correlation analysis, determination coefficient analysis, and F test and t-test. The results show that business actors must be more innovative in implementing a green marketing mix, consumers who are educated about environmentally friendly products are usually willing to buy expensive prices. Simultaneously and partially green products, green prices, green places, and green promotion have a positive and significant effect on the competitiveness of SMEs. Implementing the Green Marketing Mix requires a fundamental approach, comprehensive and integrated with all functional aspects of marketing, including the overall marketing mix.
\end{abstract}

Keywords: Green Product, Green Price, Green Place, Green Promotion, Competitiveness

\section{INTRODUCTION}

The occurrence of environmental damage caused by various economic activities requires companies to carry out activities to produce environmentally friendly products including Micro, Small, and Medium Enterprises as economic actors. The trend of demand for environmentally friendly products is also influenced by several factors, such as concern for the environment, knowledge of the environment, and perceptions of environmentally friendly products. [1] Based on data, most SMEs in the city of Bogor are still not environmentally friendly and should be of particular concern, because there are still problems faced in the development of the green industry, namely: (a) limited knowledge of environmental sustainability; (b) weak management aspects and unsupportive technical aspects; and (c) the high cost of environmentally friendly technology. Environmentally friendly products are not only seen from the perspective of consumption, but also distribution, production, and recycling. Therefore, the development of research on environmentally friendly products tends to grow and this provides an overview of the complexity of consuming environmentally friendly products. What is also interesting from research on environmentally friendly products is the approach through the marketing mix, namely the 4Ps, which underlie the linkage of all elements in the marketing mix to answer the attractiveness of consuming environmentally friendly products, especially to meet consumer wants and needs. Therefore, the important side of the $4 \mathrm{P}$ is a reference for the success of product marketing and also orientation to increase business competitiveness [2].

SMEs that consistently use the green marketing concept are still low because the innovation of environmentally friendly products is still very limited, presumably because of the high costs incurred in conducting market research and the still high prices of environmentally friendly products. [3] In the city of Bogor, the implementation of green marketing is still limited to retail business actors that have not touched SMEs but it is hoped that in the long term business actors will also implement policies to increase the competitiveness of their products.

The purpose of this study is to 1) determine the application of the green marketing mix to SMEs actors 2) to study and analyze the effect of the green marketing mix both simultaneously and partially in increasing the competitiveness of SMEs. With this research, it is expected to provide input to SMEs actors related to the application of the green marketing mix in terms of product, price, distribution channels, and promotion to attract consumers so they can compete. For the Regional Government, make contributions related to policies or regulations on the importance of using environmentally friendly products and provide recommendations for-based economic sustainable development environmentally. 


\section{LITERATURE REVIEW}

Several cases related to environmentally friendly products show various perceptions, especially about aspects of price, product quality, and the potential for post-consumption recycling, including studies on how the production process of environmentally friendly products, marketing aspects of environmentally friendly products. 4] Research related to environmentally friendly products is interesting to research because several research results show mixed results so this confirms the existence of an interesting research gap to be studied in more depth.

The phenomenon of environmentally friendly products is also inseparable from global pressure to care more about environmental management as a whole so that the production process is not only focused on efficiency and productivity but also on how to create environmentally friendly products from scratch, namely through raw materials to recycled post-consumption products. so that it has a positive impact on the commitment to zero waste in all stages of its production process, which states that the company views environmental issues as an opportunity to satisfy consumer needs and desires. [5] They will apply environmental issues in their marketing activities, causing a new phenomenon in the marketing world in the form of green marketing concepts.

The difference between the green marketing mix and the conventional marketing mix lies in the environmental approach. The green marketing mix considers environmental aspects, while the conventional marketing mix does not pay attention to environmental aspects [6] In developing the green marketing concept mix, it is inseparable from the traditional $4 \mathrm{P}$ concepts, namely products, prices, promotional activities, and distribution systems. Activities elements of the marketing mix need to be combined and coordinated so that the company can carry out its marketing tasks and programs effectively. The concept of the green marketing mix was first introduced by Bradley in the late 1980s. The researchers identified several aspects of the green marketing mix, for example, explaining how products are greened, how prices are greened, and how promotions and places/distribution channels are greened, to attract consumers [7].

\section{METHOD AND DATA ANALYSIS}

The type of research used in this study is explanatory research. This study focuses on SMEs actors in the form of food and handicrafts typical of Bogor City which is the main attraction for tourists when visiting. The number of samples in the study was 46 business actors. The sampling technique used is a simple random sampling technique, which is a random sample by taking samples from members of the sample without paying attention to the strata (levels) of the members of the population. Methods of data analysis using descriptive statistical analysis are statistics used to analyze data by describing or describing the collected sample data. The analysis is also used to determine the characteristics of the respondents as measured by several indicators asked through questionnaires, interviews, and documentation. The technique used is to use descriptive statistics to produce a frequency value and a mean value (mean) of each of the indicators being asked. For quantitative statistical calculations in research using the SPSS program. The data analysis technique is multiple linear regression analysis, the coefficient of determination of the correlation coefficient, and through statistical testing of the $\mathrm{F}$ test and t-test.

\section{DISCUSSION AND DISCUSSION RESULTS}

The majority of business actors are male with 27 people or $56 \%, 22$ people aged $41-55$ years or $46 \%$, 44 people or $92 \%$ of whom are married, with graduated education universities as many as 26 people or $54 \%$, with a business length of 0 - 5 years as many as 20 people or $42 \%$, with a monthly turnover of $<$ Rp. 300,000,000 as many as 45 people or $94 \%$ have a workforce of $<5$ as many as 28 or $58 \%$, with an initial capital of $<5,000,000$ as many as 28 people or $58 \%$, with a source of personal capital of 48 people or $100 \%$, and a source of raw materials used from the local market by 40 people or $83 \%$. The regression results can be seen in Table 1 below: 
Table 1. Summary of the Calculation Results of the Regression Equation

\begin{tabular}{|c|c|c|c|c|c|}
\hline \multirow[t]{2}{*}{ Model } & \multicolumn{2}{|c|}{$\begin{array}{l}\text { Unstandardized } \\
\text { Coefficients }\end{array}$} & \multirow{2}{*}{$\begin{array}{c}\text { Standardized } \\
\text { Coefficients } \\
\text { Beta }\end{array}$} & \multirow[t]{2}{*}{$\mathrm{T}$} & \multirow[t]{2}{*}{ Sig. } \\
\hline & $\mathrm{B}$ & Std.Error & & & \\
\hline (Constant) & 8.079 & 8.322 & & .971 & .337 \\
\hline Green Product (X1) & .900 & .141 & .602 & 6.395 & .000 \\
\hline Green Price (X2) & .744 & .247 & .287 & 3.016 & .004 \\
\hline Green Place (X3) & .736 & .282 & .241 & 2.611 & .012 \\
\hline Green Promotion (X4) & .479 & .195 & .229 & 2.461 & .018 \\
\hline
\end{tabular}

\begin{tabular}{ll}
\hline $\mathrm{t}$ tabel & $=1,681$ \\
\hline $\mathrm{R}$ & $=0,804$ \\
R Square & $=0,674$ \\
Adjusted R Square & $=0,615$ \\
F hitung & $=19,697$ \\
F tabel & $=3,59$ \\
Sig F & $=0,000$ \\
SEE & $=3,787$ \\
\hline
\end{tabular}

From the regression equation, it can be seen that the variable Green Product $\left(\mathrm{X}_{1}\right)$, Green Price $\left(\mathrm{X}_{2}\right)$ Green Place $\left(\mathrm{X}_{3}\right)$ Green Promotion $\left(\mathrm{X}_{4}\right)$ has a positive effect on Competitiveness $(\mathrm{Y})$. Shows a correlation number of 0.804, which means that Green Product, Green Price, Green Place, and Green Promotion have a strong relationship to increasing the competitiveness of SMEs. The better the implementation of the Green Marketing Mix, which includes Green Product, Green Price, Green Place, and Green Promotion, is expected to increase the competitiveness of SMEs. The coefficient of determination shows how much the percentage contribution of the influence of Green Product, Green Price, Green Place, and Green Promotion on Competitiveness. The coefficient of determination was 67.40\%. This shows that the percentage contribution of the influence of Green Product, Green Price, Green Place, and Green Promotion on the increase in the competitiveness of SMEs is $67.40 \%$. Meanwhile, $32.60 \%$ that were not examined were workers' skills or education levels, entrepreneurial skills, availability of capital, good organizational and management systems, availability of technology, availability of information, and availability of other inputs such as energy, raw materials, and others [8].

Based on the value, it is calculated known that the F count is 19.697 and the $\mathrm{F}$ table value is 3.59 so that Fount (19.679)> F table (2.58), it can be concluded that simultaneously the variables Green Product, Green Price, Green Place, and Green Promotion has a positive and significant effect on the variable business competitiveness. This is by the results of research conducted by [9] which states that green marketing consisting of green products, green prices, green places, and green promotions simultaneously has a positive and significant effect on competitiveness. From the above table also shows that the Green Product (X1) on the Competitiveness of SMEs (Y), from the calculation of value t count for Green Product of 6.395 and $t$ table of 1.681, because $t$ count 6.395>0.000 1,681dengan probability $(<0.05)$ said that the Green Product has a positive and significant effect on the Competitiveness of SMEs (Y). Green Price (X2) on the Competitiveness of SMEs (Y) from the calculation of the value of ${ }_{t}$ for Green Price of 8.858 and $t$ table of 1.681 , because $t$ count $8.858>0.0001,681$ dengan probability $(<0.05)$ said that Green Price effect positive and significant towards SMEs Competitiveness (Y). Green Place (X3) on the Competitiveness of SMEs (Y) from the calculation of value $t$ the count for Green Place at 13.887 and $t$ table of 1.681 , because $t$ 13.887> 1,681dengan probability of $0.000(<0.05)$ said that Green Place influential positive and significant towards SMEs Competitiveness (Y). Green Promotion (X4) on the performance of the calculation result value ${ }_{t}$ for Green Promotion of 4.651 and $t$ table of 1.681 , because t $4.651>1.681$ with a probability of $0.000(<0.05)$ said that Green Promotion affect positively and significantly to Power SMEs Competitiveness (Y).

Good green marketing implementation is not only done on one indicator but all indicators in the green marketing mix. In its application, SMEs in the City of Bogor has implemented green marketing well. This can be seen through several indicators of the green marketing mix, namely products, distribution channel prices, and promotions. Some actor's businesses use recyclable raw materials, thereby reducing costs, reducing raw materials, reducing pollution, and environmental damage. As was done to NH SMEs. Collection and Bamboo Tronik, Khabeesa Craft, and Talitha Art which have raw materials that can be recycled such as paper, wood, bamboo, plastic packaging, and plastic bottles. Things that need to be considered in the application of green products are ensuring the products produced are according to standards and saving energy and resources in processing, using, and selling products. 
Eco-friendly products usually have an increase in product prices. This is what distinguishes the price of conventional products. Consumers who are educated on environmentally friendly products are usually able to be willing to buy a high price from the usual price. The desire of consumers to pay a certain amount of money for environmentally friendly products is more due to their concern for environmental problems [10]. The acceptance of a premium price factor for environmentally friendly products which is then often defined as green prices. Eco-friendly products are often cheaper if the cost of the product life cycle is considered. This condition shows that business actors use environmentally friendly features in distribution activities. This is demonstrated by business actors by distributing products using simple packaging, shopping bags environmentally friendly, and using fuel-efficient vehicles. This condition shows that business actors are making efficiency in distribution activities. [11] In connection with the changing competitive environment and the pressure faced by the organization, synergies must be built by combining the company, distribution channels, and flexible technical capabilities. Several previous studies have shown that the development of quality channel relationships is the result of synergies that are built with the company's capabilities and resources within the company as well as expertise that is rooted in the concept of success in product marketing channels.

Promotion in green marketing is carried out while still paying attention to the use of environmentally friendly promotional media. The implementation of green marketing has been carried out by SMEs by the green marketing mix that the marketing mix in green marketing focuses on ecological benefits and pays more attention to minimizing waste and pollution. [12] Green marketing has been done well by the company because every indicator of the marketing mix in green marketing has reduced environmental impacts and preserved environmental sustainability. [13] The research concluded that the implementation of green marketing in the internal company is an increase in the safety and comfort of the work of employees, while the external company is an increase in consumer confidence so that they can compete with other products. This is confirmed by research that implementing a marketing mix strategy is inseparable from the traditional $4 \mathrm{P}$ concept (product, price, place, promotion) unless it is related to several additional components of green marketing itself or other very influential things. [14] Then the final results of this study have relatively the same results as several previous studies related to the application of green marketing in food SMEs [15] as well as research conducted on MSMEs in the Semarang Regency. [16] The final results of this study show results that are in line with those using the same marketing mix indicators as researchers and produce conclusions that both show that the company has implemented green marketing well in the marketing mix indicator [17].

\section{SUMMARY}

The Marketing Mix simultaneously has a positive and significant effect on the competitiveness of SMEs. Partially green products, green prices, green places, and green promotion have a positive and significant effect on the competitiveness of SMEs. SMEs players have implemented green products well, marked by-products produced according to Indonesian national standards (SNI), have halal labels for food SMEs, are safe for consumption, and business actors can control production waste. The price of eco-friendly products is usually higher than that of ordinary products because of the connection with technology and innovation. Business actors use environmentally friendly features in distribution activities. This is demonstrated by distributing products using simple packaging, environmentally friendly shopping bags. Promotion is carried out while paying attention to the use of environmentally friendly promotional media. Business actors in their promotional activities contain environmentally friendly product labels to attract consumers. This is shown by business actors with the presence of environmentally friendly stickers, recycled labels, and an invitation to care for the environment on every product packaging.

\section{IMPLICATIONS / LIMITATIONS AND SUGGESTIONS FOR FURTHER RESEARCH}

The suggestions that can be conveyed are as follows:

1. Business actors must be more innovative in producing environmentally friendly products by paying attention to matters related to the criteria for environmentally friendly products.

2. Prices set from the application of green marketing adjust to the cost of production issued in the application of green marketing.

3. Business actors in distribution activities make it easier for the chain supply product. This is shown by the company by shortening the distribution channels and loading many products in one distribution by reaching many places.

4. Promotion is further enhanced through media with a wider reach.

5. The findings of this research have not identified the overall attractiveness of consumption of environmentally friendly products so that consideration of the generalization of the results cannot be proven. It is expected to add variables that can attract consumers to care about environmentally friendly products. 


\section{Acknowledgments}

The authors would like to thank the Directorate of Research and Community Service, Directorate General of Research and Development Strengthening, Kemenristekdikti for funding this research.

\section{REFERENCES}

[1] M. Nasir and E. P. Saputro, "Daya tarik produk ramah lingkungan," Semin. Bisnis Magister Manaj. “Membangun Ekon. Kreat. yang Berdaya Saing," pp. 189-198, 2019.

[2] F. Rahman, P. S. Siburian, and G. N. A, "Pengaruh Green Marketing Mix terhadap Keputusan Pembelian Konsumen Produk Tupperware di Samarinda," Forum Ekon., vol. 19, no. 1, p. 119, 2017, doi: 10.29264/jfor.v19i1.2118.

[3] Delmayuni, M. Hubies, and R. Cahyadi Eko, "STRATEGI PENINGKATAN DAYA SAING UMKM PANGAN DI PALEMBANG Strategies to Increase the Competitiveness of Food's Small Medium Enterprises (SMEs) in Palembang," Bul. Ilm. Litbang Perdagang., vol. 11, no. N01, pp. 97-122, 2017.

[4] S. Rahayu, "Strategi pemasaran hijau sebagai upaya meningkatkan keunggulan bersaing," vol. 15, no. 2, pp. 263-270, 2017.

[5] D. Islam and U. T. Madura, "Tinjauan Penerapan Konsep Green Marketing,” vol. 11, no. 1, pp. 10-18, 2018.

[6] I. Risyamuka and K. Mandala, "Pengaruh Green Marketing Terhadap Keputusan Pembelian Produk Hijau Di Restoran Sari Organik Ubud," E-Jurnal Manaj. Univ. Udayana, vol. 4, no. 2, p. 246521, 2015.

[7] W. B. Atmoko and D. Setyawan, "Green Marketing: Memperkuat Daya Saing Merek," pp. 978-979, 2013.

[8] Tulus Tambunan, "Ukuran Daya Saing Koperasi Dan UKM," Badan Perenc. Pembang. Nas., no. 1997, pp. $1-30,2008$.

[9] "Inovasi Dan Pengembangan Produk Ukm Handikraf Untuk Pasar Pariwisata Di Bali," Profit - J. Adm. Bisnis, vol. 10, no. 2, pp. 52-64, 2007, doi: 10.9876/10.9876/VOL1ISSN1978-743X.

[10] I. Hendarsih, "Analisis Konsep Green Product Sebagai Pelaksanaan Etika Bisnis Pada Perusahaan," Widya Cipta - J. Sekr. dan Manaj., vol. 1, no. 1, pp. 76-85, 2017, [Online]. Available: http://ejournal.bsi.ac.id/ejurnal/index.php/widyacipta/article/view/1589.

[11] A. Hanifah, Z. Arifin, and K. Hidayat, "PENGARUH BAURAN PEMASARAN BERWAWASAN GREEN MARKETING TERHADAP KEPUTUSAN PEMBELIAN (Survei pada Pembeli yang Menghuni Perumahan Ijen Nirwana Malang)," J. Adm. Bisnis S1 Univ. Brawijaya, vol. 32, no. 2, pp. 23-32, 2016.

[12] F. INDRIANI, "Studi Mengenai Inovasi Produk Pada Usaha Kecil Kerajinan Ukiran Di Jepara," J. Sains Pemasar. Indones., vol. 7, no. 2, 2008.

[13] N. Ajizah and S. Suharyono, "ANALISIS PENERAPAN GREEN MARKETING PADA PRODUK NAOOGST CIGAR SEBAGAI STRATEGI PEMASARAN INTERNASIONAL (Studi pada PTPN X),” $J$. Adm. Bisnis S1 Univ. Brawijaya, vol. 51, no. 2, pp. 8-15, 2017.

[14] S. Susanti, "Optimalisasi Strategi Green Product Terhadap Perkembangan Umkm Di Bandar Lampung Ditinjau Dari Etika Bisnis Islam," Fak. Ekon. Dan Bisnis Islam Univ. Islam Negeri Raden Intan Lampung, 2017.

[15] E. Sugiono and S. Efendi, "Strategi Peningkatan Keunggulan Bersaing Ikm: Peran Pembelajaran Organisasi Dan Inovasi," J. Ris. Manaj. dan Bisnis Fak. Ekon. UNIAT, vol. 4, no. 1, pp. 45-56, 2019, doi: 10.36226/jrmb.v4i1.241.

[16] D. J. Negara and V. Kristinae, "Pengaruh Teknologi dan Inovasi dalam Persaingan Traditional Food di Kalimantan Tengah," JMD J. Ris. Manaj. Bisnis Dewantara, vol. 2, no. 1, pp. 45-52, 2018, doi: 10.26533/jmd.v2i1.347.

[17] S. K. Anggraeni, M. S. Maarif, Sukardi, S. Raharja, and Harjo, "Strategi Peningkatan Daya Saing Usaha Kecil Menengah Berbasis Olahan Ikan di Indonesia: Suatu Tujuan," J. Ind. Serv., vol. 3, no. 1, pp. 331-341, 2017. 